\title{
Saudi EFL Learners' Perceptual Learning-Style Preferences
}

\author{
Alya Khalil \\ English Language Institute, King Abdulaziz University \\ PO Box 80200, Jeddah 21589, Saudi Arabia \\ Tel: 966-126-400-000Ｅ-mail: aekhleel@kau.edu.sa \\ Mona Sabir (Corresponding author) \\ English Language Institute, King Abdulaziz University \\ PO Box 80200, Jeddah 21589, Saudi Arabia \\ Tel: 966-126-400-000Ｅ-mail: msabir@kau.edu.sa
}

Received: October 14, 2019

Accepted: October 25, 2019 Published: October 27, 2019

doi:10.5296/elr.v5i2.15711

URL: https://doi.org/10.5296/elr.v5i2.15711

\begin{abstract}
Identifying students' learning styles is advantageous for both teachers and students. Awareness of students' learning styles allows teachers to plan lessons to reach each student in the classroom by providing proper activities and classroom materials that suit every individual. Furthermore, students can raise their own awareness of the learning process and maximize their opportunities to learn by knowing their preferred learning styles. Using the Perceptual Learning Style Preference Questionnaire, this study aims to investigate Saudi EFL students' preferred learning styles and explore whether these learning styles are affected by students' academic majors. The participants were 120 Saudi students at a private college in four different majors. The results show that the kinaesthetic learning style is the most commonly preferred learning style among students of all majors. Based on the findings, pedagogical implications and directions for further research are highlighted.
\end{abstract}

Keywords: Learning styles, EFL learners, Academic majors

\section{Introduction}

'Learning Style' concept validity is controversial. Although it has been widely accepted as a 
pedagogical tool by many educators, many opposing views towards this concept exist. Unlike the proponents of the concept of learning styles, those who oppose the adoption of learning style approaches believe that there is no empirical evidence supporting that the adjustment of teaching strategies to match each student's preferred learning style would improve educational outcomes. Therefore, this research provides empirical support for the effectiveness of considering learning styles by looking at whether learners in different academic majors tend to differ in their learning styles. Reid (1995) asserts that allowing students to understand the concept of learning styles "will enable students to take control of their learning and to maximise their potential for learning”. Similarly, Svinicki (1999) stated that learners' involvement in their educational process results in better achievement. He added that learning theories and views have changed from the behaviouristic approach where learning was regarded as mere imitation to the cognitive view where learners are cognitively involved in the learning process. Hawk and Shah (2007) confirmed that having a unified teaching approach does not lead to effective learning as students tend to learn differently. Consequently, matching teaching strategies with students' learning styles is an area that offers interesting implications for language learning.

This paper starts with a background on learning styles. Subsequently, Reid's (1995) Perceptual Learning Style model which this study adopts is reviewed. Finally, the research questions and the details of this study are presented.

\section{Learning Styles}

Several definitions for learning styles have been proposed by many scholars. For example, Reid (1998, p.ix) defined learning styles as internally "based characteristics, often not perceived or consciously used by learners, for the intake and comprehension of new information", while Scarcella's (1990) definition was "cognitive and interactional patterns which affect the ways in which students perceive, remember, and think". An alternate definition found in the literature is a "stable and pervasive characteristics of an individual, expressed through the interaction of one's behaviours and personality as one approaches a learning task" (Garger \& Guild, 1984).

Thus, the term 'learning styles' is usually associated with the modalities through which individuals process given information. Riding and Rayner (1995) stated that every student learns in a different way. On the other hand, Johnson (1999) argued that teachers' teaching strategies reflect their learning styles. However, some research indicated that higher educational achievement is usually correlated with a match between students' learning styles and teachers' teaching styles (Yu \& Banya, 1998). Learners, therefore, should have "ample opportunity to learn through their preferred style, [and] they also need to be open to the idea of "style flex"- that is, students should be encouraged to diversify their style preferences" (Kroonenberg, 1995). Such diversity can be reached through teachers' abilities to adapt their teaching styles in class based on their students' learning styles. As a result, learners might be indirectly pushed towards developing learning styles other than their own (Mosston \& Ashwworth, 1990).

Banner and Rayner (1997), furthermore, stated that a student's learning style is comprised of 
two important dimensions that shape thinking, and processing given information. The first dimension is verbal imagery structure which guides thinking. The second dimension represents the way by which learners process information as either analytically or holistically. Consequently, there are numerous learning style models which result in learners reacting differently to the language learning (Tyacke, 1998). However, each model is criticised in a way as it is difficult to identify the learning style of each learner. Thus, teachers have to consider several points. First, it is difficult to analyse a student's learning profile as learning styles are usually complex. Second, if learning styles are associated with particular leaning goals, then students might adopt different learning styles in different contexts of learning. Third, sometimes an educational system might impose a certain method that caters for one learning style, but not others (Tyacke, 1998).

Based on the literature, the most comprehensive learning style models are those based on the work of Carl Jung's psychological types. Jung looked at two dimensions: perception and judgment and combined them into four types: sensing (step by step thinking and concreteness), thinking (logic and objectivity), feeling (emotion and spontaneity), and intuition (insight and abstraction). Followers of Jung have elaborated on these ideas. Cherry (1993), for example, stated that an individual's learning style may include a mixture of these factors.

\section{Reid's Perceptual Learning Style Preference Model}

Several models of learning styles have been prosed (Dunn \& Dunn 1978; Kolb, 1984; Gregorc, 1979; Violand-Sanchez, 1995), but this study is well-suited to Reid's (1995) model. Reid (1995, p.viii) stated that "individuals have different learning styles; as a result, they differ in their 'natural, habitual, and preferred way(s) of absorbing, processing, and retaining new information and skills". Reid (1995) designed a perceptual learning style questionnaire which helps students determine what facilitates their learning by discovering their preferred learning style. Consequently, we propose that Reid's questionnaire can be used by teachers in this study to find out more about their students' preferred learning styles and to adjust their teaching strategies accordingly.

According to Reid (1995), some people learn mainly with their eyes and thus called (visual learners). Others learn with their ears (auditory learners). Furthermore, some individuals prefer to learn by experiences (kinaesthetic learners) or by 'hands-on' tasks (tactile learners). Some people learn better when they work individually, while others prefer group work. In this regard, a questionnaire was designed by Reid (1995) who found that his ESL participants preferred kinaesthetic and tactile learning styles over audio and visual learning styles. His study was replicated by Stebbins (1995) who found similar results.

For the purpose of this study, Reid's approach was adopted for several reasons. First, his approach relies on sensory modality of learning styles. Second, it aims at exploring learning styles of individuals and thus promoting active learning by making students aware of their learning style which leads them to be more engaged during the learning process. These results will be achieved when teachers know how to reach each student. By adopting this approach, we seek to shed light on some questions: how can we manage effective teaching 
and learning in light of learning styles, how can teachers cater to individual differences, and can students adapt to different learning styles with practice? This study uses Reid's questionnaire to find out Saudi EFL learners' preferred learning styles and whether these learning styles differ based on their academic majors.

\section{Aim of the Study}

The purpose of this study is to identify Saudi EFL students' learning styles based on the perceptual learning style preference model. Furthermore, the study aims to find differences in learning styles related to students' academic majors.

Knowing students' learning styles can help teachers support their students with activities that match their preferred learning styles. It is also predicted that by knowing their style of learning, students will be able to improve the way they learn and try to modify their learning styles based on their academic major/specific course requirements.

Thus, the main aim of this research is to raise Saudi EFL learners' awareness of their own learning styles to enhance the learning process and to see whether their preferred learning styles are affected by their academic majors and its teaching discipline.

\section{Research Questions}

The study focuses on two research questions.

A) What are Saudi EFL learners' preferred learning styles based on the perceptual learning style preference model?

B) Do Saudi EFL learners' preferred learning styles correspond to their academic majors from the perspective of the perceptual learning style preference model?

\section{Methodology}

\subsection{Participants}

The participants were 120 Saudi EFL students at Dar AL-Hekma College, which is a private college in Jeddah, Saudi Arabia. They were divided into four groups based on their academic majors: 30 architecture students, 30 law students, 30 speech and hearing students, and 30 education students. Their ages ranged between 17-21 years old. They were classified as advanced and upper-intermediate EFL learners based on their TOEFL grades. At Dar Al-Hekma, students have to score at least 500 on the TOEFL test to be admitted to the college which equals 5 in EILTS measure.

\subsection{Instrument}

The study adopted the perceptual learning style preference questionnaire (PLSPQ) developed by Reid (1995) to identify the perceptual learning style preferences of the Saudi students at Dar Al-Hekma College (see Appendix 1). To suit the purpose of the study, the questionnaire was translated into Arabic to ensure that students understood the questions well and chose the answers that reflected their actual learning style preferences. The students were requested to answer spontaneously without taking a long time thinking. 


\section{Macrothink

The questionnaire included 30 questions that measured six learning style preferences: visual, auditory, tactile, kinaesthetic, group learning, and individual learning. Each learning style preference was covered by five questions. The questions were randomized in the questionnaire so that learners' attention was not drawn to specific learning styles. The PLSPQ is a self-scoring instrument that comes with a self-scoring scoring sheet (see Appendix 2). This scoring sheet categorizes responses into six categories of learning style: visual, tactile, auditory, kinaesthetic, individual, and group.

Furthermore, the instrument was accompanied by an explanation of the learning style preferences (Appendix 3). This sheet shows a detailed description of the characteristics of students who have these learning styles preferences. It also contains a definition of minor learning styles.

\subsection{Procedure}

After writing the plan for this study, an email was sent to the dean of Dar Al-Hekma College to obtain permission for conducting the study. A consent was signed by the participants. The questionnaire was piloted on a small number of participants and then distributed to the 120 students. The participants were given detailed instructions on how to answer the questionnaire and what was expected from them.

\section{Data Analysis and Results}

Two steps were used to analyse the data collected. First, the questionnaire was analysed using the PLSPQ's self-scoring sheet developed by Reid (1995) to determine the perceptual learning style of each participant. Table 1 below shows the grouping of the thirty statements.

Table 1. The grouping of the PLSPQ's statements according to their learning styles categories. The respondents' degrees of agreement were reflected by five choices: 5 means strongly agree, 4 means agree, 3 means undecided, 2 means disagree, and 1 means strongly disagree.

\begin{tabular}{|c|c|c|}
\hline $\begin{array}{l}\text { Learning Style } \\
\text { Category }\end{array}$ & $\begin{array}{l}\text { Number of } \\
\text { Statements }\end{array}$ & The Statements \\
\hline \multirow[t]{5}{*}{ Visual } & 6 & $\begin{array}{l}\text { I learn better by reading what the teacher writes on the } \\
\text { chalkboard. }\end{array}$ \\
\hline & 10 & When I read instructions, I remember them better. \\
\hline & 12 & I understand better when I read instructions. \\
\hline & 24 & I learn better by reading than listening to someone. \\
\hline & 29 & $\begin{array}{l}\text { I learn more by reading textbooks than listening to } \\
\text { lectures. }\end{array}$ \\
\hline \multirow[t]{3}{*}{ Auditory } & 1 & $\begin{array}{l}\text { When the teacher tells me the instructions, I understand } \\
\text { better. }\end{array}$ \\
\hline & 7 & $\begin{array}{l}\text { When someone tells me how to do something in class, I } \\
\text { learn it better. }\end{array}$ \\
\hline & 9 & I remember things I have heard in class better than things \\
\hline
\end{tabular}




\begin{tabular}{|c|c|c|}
\hline & & I have read. \\
\hline & 17 & I learn better in class when the teacher gives a lecture. \\
\hline & 20 & I learn better in class when I listen to someone. \\
\hline \multirow[t]{5}{*}{ Kinaesthetic } & 2 & I prefer to learn by doing something in class. \\
\hline & 8 & When I do things in class, I learn better. \\
\hline & 15 & I enjoy learning in class by doing experiments. \\
\hline & 19 & $\begin{array}{l}\text { I understand things better in class when I participate in } \\
\text { role playing. }\end{array}$ \\
\hline & 26 & $\begin{array}{l}\text { I learn best in class when I can participate in related } \\
\text { activities. }\end{array}$ \\
\hline \multirow[t]{5}{*}{ Tactile } & 11 & I learn more when I can make a model of something. \\
\hline & 14 & I learn more when I make something for a class project. \\
\hline & 16 & I learn better when I make drawings as I study. \\
\hline & 22 & $\begin{array}{l}\text { When I build something, I remember what I have learned } \\
\text { better. }\end{array}$ \\
\hline & 25 & I enjoy making something for a class project. \\
\hline \multirow[t]{5}{*}{ Group } & 3 & I get more work done when I work with others. \\
\hline & 4 & I learn more when I study with a group. \\
\hline & 5 & In class, I learn best when I work with others. \\
\hline & 21 & $\begin{array}{l}\text { I enjoy working on an assignment with two or three } \\
\text { classmates. }\end{array}$ \\
\hline & 23 & I prefer to study with others. \\
\hline \multirow[t]{5}{*}{ Individual } & 13 & When I study alone, I remember things better. \\
\hline & 18 & When I work alone, I learn better. \\
\hline & 27 & In class, I work better when I work alone. \\
\hline & 28 & I prefer working on projects by myself. \\
\hline & 30 & I prefer to work by myself. \\
\hline
\end{tabular}

Table 2. Summary of four examples of the calculations of the perceptual learning styles as performed in the self-scoring sheet

\begin{tabular}{llllll}
\hline $\begin{array}{l}\text { Learning } \\
\begin{array}{l}\text { Style } \\
\text { Category }\end{array}\end{array}$ & $\begin{array}{l}\text { Number of } \\
\text { Statements }\end{array}$ & $\begin{array}{l}\text { The Numerical Value of the Statements for: } \\
\text { Architecture }\end{array}$ & Law & $\begin{array}{l}\text { Speech and } \\
\text { Hearing }\end{array}$ & Education \\
\hline Visual & 6 & 5 & 5 & 5 & 5 \\
& 10 & 4 & 5 & 4 & 5 \\
& 12 & 4 & 5 & 5 & 5 \\
& 24 & 2 & 2 & 5 & 5 \\
& 29 & 2 & 4 & 5 & 5 \\
Total & & $17 \times 2=34$ & $21 \times 2=42$ & $24 \times 2=48$ & $25 \times 2=50$ \\
Auditory & 1 & 5 & 5 & 5 & 5 \\
& 7 & 5 & 4 & 5 & 5 \\
\hline
\end{tabular}




\begin{tabular}{|c|c|c|c|c|c|}
\hline & 9 & 5 & 3 & 5 & 5 \\
\hline & 17 & 4 & 5 & 4 & 5 \\
\hline & 20 & 3 & 5 & 5 & 5 \\
\hline Total & & $22 \times 2=44$ & $22 \times 2=44$ & $24 \times 2=48$ & $25 \times 2=50$ \\
\hline \multirow[t]{5}{*}{ Kinaesthetic } & 2 & 5 & 5 & 5 & 5 \\
\hline & 8 & 5 & 4 & 5 & 5 \\
\hline & 15 & 5 & 4 & 5 & 5 \\
\hline & 19 & 4 & 4 & 5 & 2 \\
\hline & 26 & 5 & 4 & 4 & 2 \\
\hline Total & & $24 \times 2=48$ & $21 \times 2=42$ & $24 \times 2=48$ & $19 \times 2=38$ \\
\hline \multirow[t]{5}{*}{ Tactile } & 11 & 5 & 5 & 5 & 5 \\
\hline & 14 & 5 & 5 & 5 & 5 \\
\hline & 16 & 5 & 2 & 5 & 2 \\
\hline & 22 & 5 & 4 & 5 & 5 \\
\hline & 25 & 5 & 3 & 5 & 5 \\
\hline Total & & $25 \times 2=50$ & $19 \times 2=38$ & $25 \times 2=50$ & $22 \times 2=44$ \\
\hline \multirow[t]{5}{*}{ Group } & 3 & 5 & 4 & 1 & 5 \\
\hline & 4 & 2 & 4 & 3 & 4 \\
\hline & 5 & 5 & 4 & 4 & 5 \\
\hline & 21 & 4 & 5 & 3 & 5 \\
\hline & 23 & 2 & 2 & 3 & 5 \\
\hline Total & & $18 \times 2=36$ & $19 \times 2=38$ & $14 \times 2=28$ & $24 \times 2=48$ \\
\hline \multirow[t]{5}{*}{ Individual } & 13 & 5 & 4 & 5 & 5 \\
\hline & 18 & 4 & 4 & 5 & 5 \\
\hline & 27 & 3 & 4 & 4 & 5 \\
\hline & 28 & 2 & 4 & 5 & 5 \\
\hline & 30 & 2 & 4 & 5 & 5 \\
\hline Total & & $16 \times 2=32$ & $20 \times 2=40$ & $24 \times 2=48$ & $25 \times 2=50$ \\
\hline
\end{tabular}

The results of each category were compared as shown in Table 3 to determine the participants' learning styles. For example, Case 1 in architecture has auditory, kinaesthetic, and tactile learning styles shown by her scores in these categories which are between 38 and 50 (she scored 44, 48, and 50 in these categories, respectively), while she scored 37 in social learning style and 36 in individual learning style.

Table 3. The interpretation of the score scales of the PLSPQ

\begin{tabular}{cc}
\hline Major learning style preference(s) & score: $38-50$ \\
Minor learning style preference(s) & score: $25-37$ \\
Negligible learning style preference(s) & score: $0-24$ \\
\hline
\end{tabular}




\section{Macrothink}

In general, architecture, law, and speech and hearing students show preference for the kinaesthetic learning style as their main learning style while the rest of the categories were classified as minor learning styles. On the other hand, education students showed preference for the auditory learning style. These results are represented in the figures below.

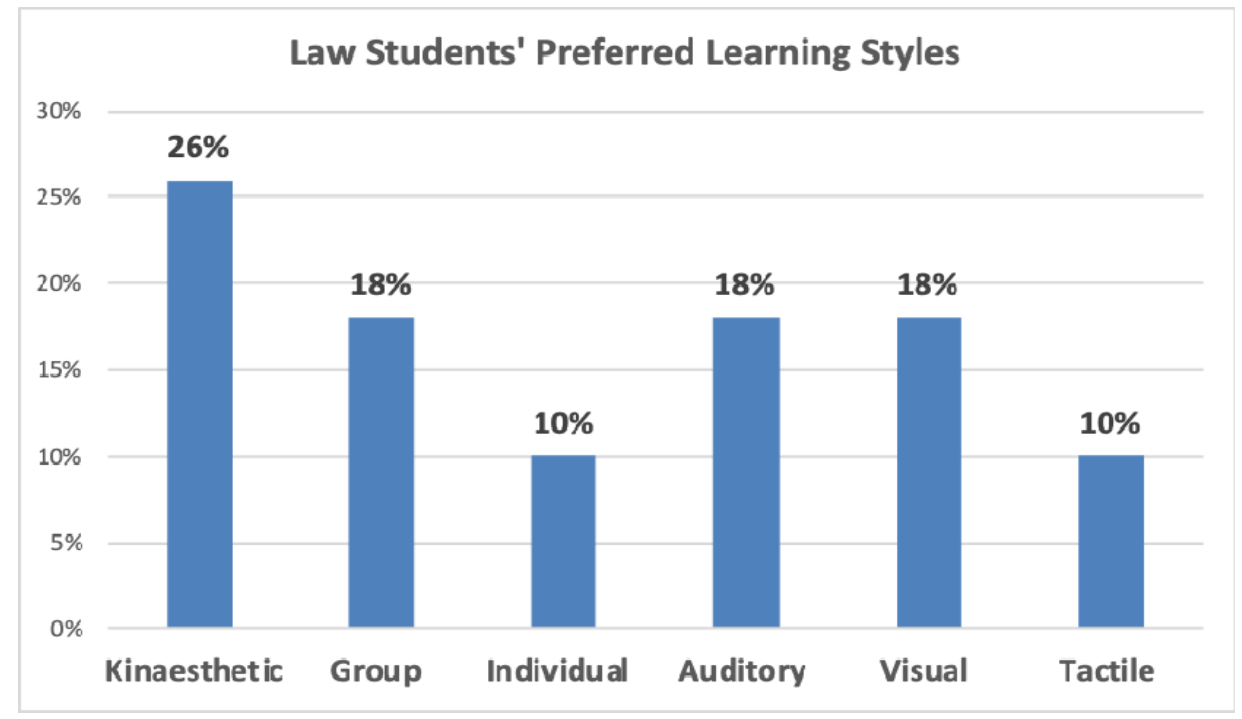

Figure 1. Law students' preferred learning styles

It is worth noting that law students prefer to work in groups rather than individually. Moreover, the tactile style is their least favourite style, while visual and auditory styles are equally preferred. Thus, they have equal preferences for learning by reading or listening.

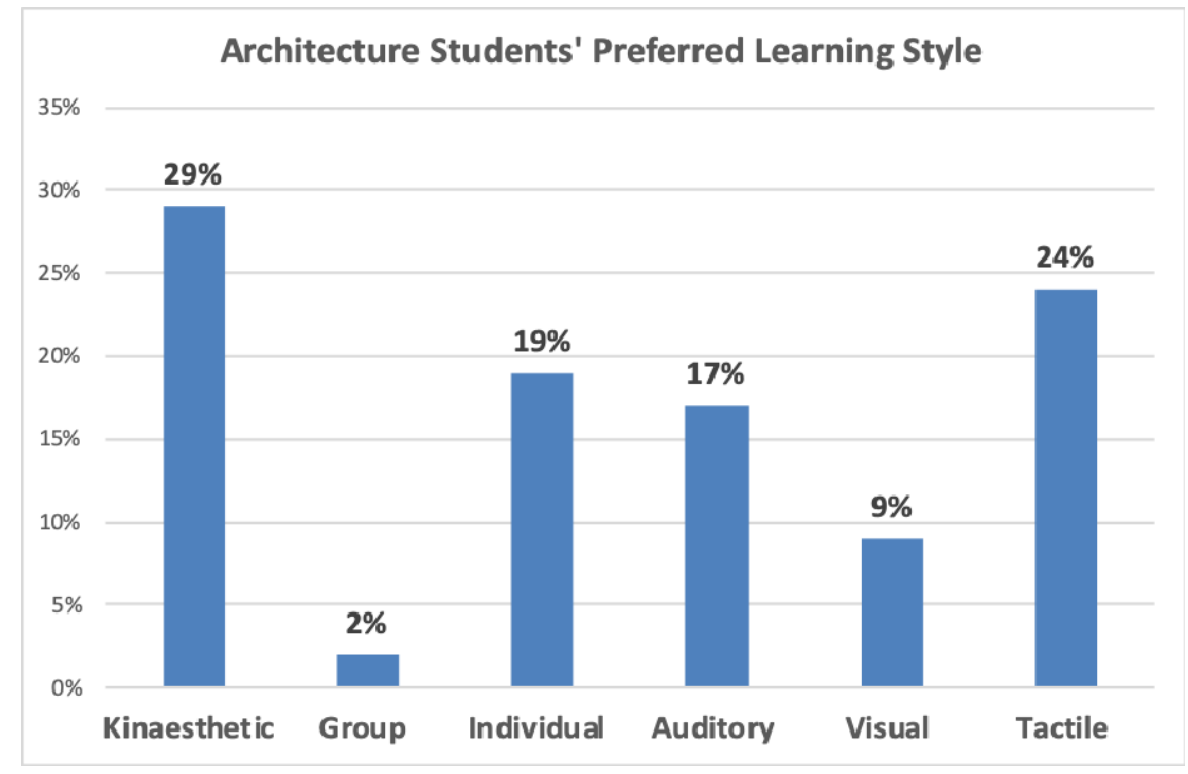

Figure 2. Architecture students' preferred learning styles 


\section{Macrothink}

Architecture students also prefer to work individually. This could be attributed to the requirements of their study program as they are usually instructed to do projects individually. The results further show that their preference for the visual learning style is minor.

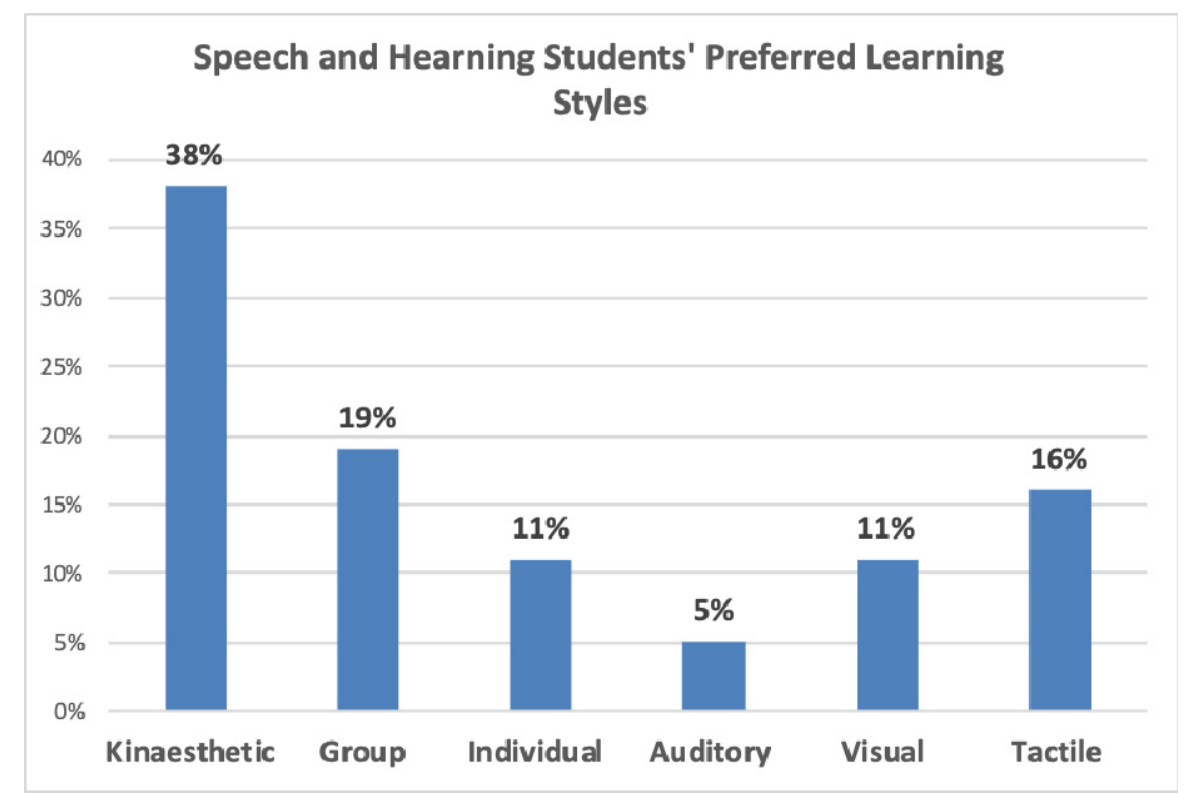

Figure 3. Speech and Hearing students' preferred learning styles

Like architecture and law students, speech and hearing students prefer the kinaesthetic learning style; nevertheless, they prefer group work unlike architecture students.

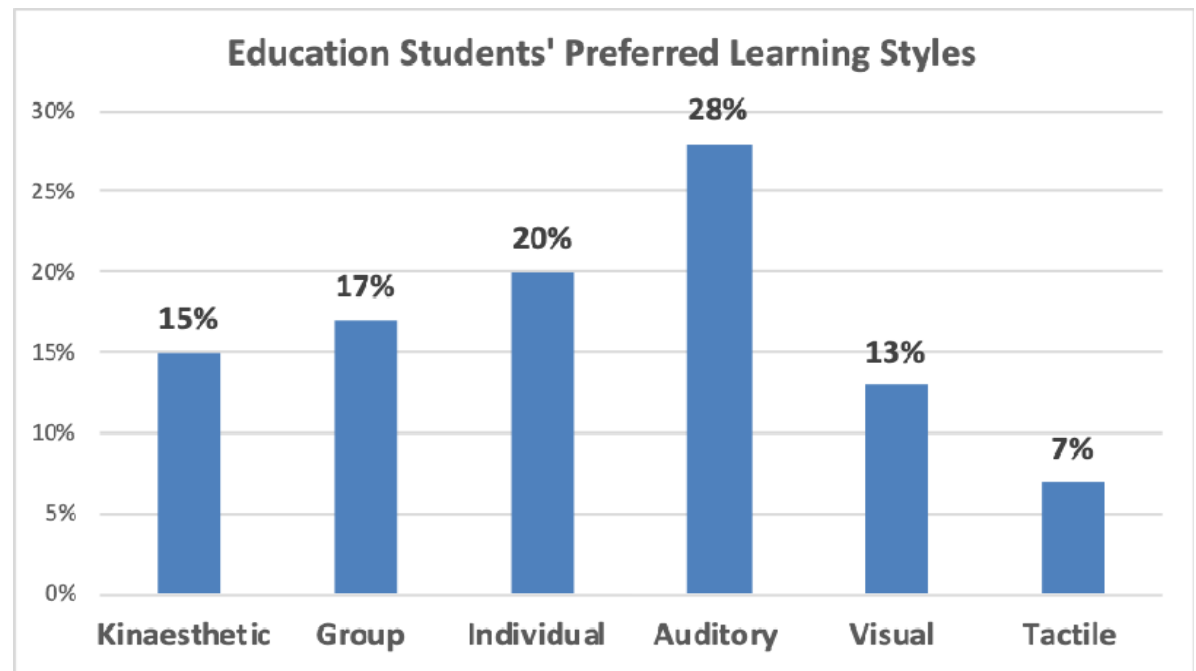

Figure 4. Education students' preferred learning styles 
Finally, education students were found to be mainly auditory. They differ in this from students in the other majors.

\section{Findings}

To sum up, the results of the questionnaire show that the perceptual learning styles of the Saudi students in architecture, law, speech and hearing, and education majors differ. However, the study suggests that the kinaesthetic learning style is the most common learning style among all students in the study which is consistent with Reid's (1995) and Stebbins' (1995) findings. Thus, the kinaesthetic learning style is considered their main preference and the rest of the learning styles were classified as minor learning preferences.

Although not directly tested, the results suggest that students' learning styles might be different based on their majors and the strategies of teaching used for each major. The results show that there is a difference between the learning styles of students in different majors. Architecture students, for example, prefer to work individually. They also prefer kinaesthetic and tactile learning styles while they consider the other styles as minor. The group learning style yielded the same result as Reid's (1995) which indicated that most groups showed little preference for group learning. Furthermore, law students showed preference for kinaesthetic as their main learning style. Auditory and visual learning styles come second for the law students who also showed some preference for working in groups. Speech and hearing students also preferred the kinaesthetic learning style, followed by the tactile learning style and they also prefer working in groups. Finally, education students prefer the auditory and kinaesthetic styles as their main learning styles and they also prefer to work individually.

\section{Discussion and Conclusion}

The two aims of the current study are to identify the perceptual learning styles of 120 Saudi EFL students at Dar Al-Hekma College and to examine the differences between the perceptual learning styles of architecture, law, speech and hearing, and education students.

These two aims have been achieved through the perceptual learning style preference questionnaire. A self-scoring sheet was used to analyse the data collected. The results of these analyses show primary preference for the kinaesthetic learning style followed by the auditory and tactile styles.

Only law and speech and hearing students showed preferences for group work learning styles. These results contradict Phoenix (2004) who found that his participants tend to prefer to work in groups which is the opposite of the findings from the current study where architecture students showed preference to work individually.

The previous result could be attributed to the effect of the academic major on students' learning styles. That is, architecture students might be affected by their curriculum requirements that accustom them to working individually, while law and speech and hearing students prefer to work in groups possibly because they are required to submit group projects. This shows that learning styles are dynamic in the sense that students can adapt to different styles if the system prepares them for it and requires it. This idea also leads us to the answer of the second research question which is whether there are any differences in the preferred 
learning styles in different academic majors. Generally, the students in the four majors tested showed preference for the kinaesthetic learning style as their main learning style which could be a result of the fact that they are all students of the same college.

In conclusion, the perceptual learning styles of Saudi students were classified as main and minor preferences. The main learning style preferences are kinaesthetic, tactile, and auditory. On the other hand, the individual learning style is minor for all groups except architecture students who are affected by the curriculum of their program and their academic needs. This leads us to the conclusion that learning styles can be adapted and teachers can direct students to use learning styles different from theirs to achieve more in the learning process.

The current study contributes to more understanding of the learning style preferences of Saudi EFL students at Dar Al-Hekma College. It also raises awareness among students on their own learning styles. Generally, if students are aware of their learning styles, they will be more aware of the learning process and more aware of their learning needs. Thus, they can enhance their learning by adjusting their learning styles.

Moreover, the present study provides some information about the differences among students and how the academic major and the system of study can affect the students' learning styles. This finding implies that just as students can adapt to teaching styles, teachers can adapt to their students' learning styles when designing lesson material to enhance their learning. Knowing the learning styles of their students, teachers will be able to offer a wide variety of activities and instruction methods that both appeal to and challenge their students.

\section{References}

Banner, G., \& Rayner, S. (1997). Teaching in style: Are you making the difference in the classroom? Support for Learning, 12(1), 15-18. https://doi.org/10.1111/1467-9604.00004

Dunn, R., \& Dunn, K. (1978). Teaching students through their individual learning styles. Reston, VA: Reston.

Garger, S., Guild, P. (1984). Learning styles: The crucial differences. Curriculum Review, 23, 9-12.

Hawk, T. F., \& Shah, A. J. (2007). Using learning style instruments to enhance student learning. Decision Science Journal of Innovative Education, 5(1), 1-19. https://doi.org/10.1111/j.1540-4609.2007.00125.x

Johnson, K. (1999). Understanding language teaching: Reasoning in action. Heinle \& Heinle.

Kolb, D. (1984). Experiential learning: Experience as the source of learning and development. Englewood Cliffs, NJ: Prentice-Hall.

Kroonenberg, N. (1995). Meeting language learners' sensory-learning-style preferences. In J. Reid (Ed.), Learning styles in the ESL/EFL classroom. Heinle \& Heinle.

Oxford, R. L. (1990). Language learning strategies: What every teacher should know. Boston, MA: Heinle \& Heinle. https://escholarship.org/content/qt1446j36q/qt1446j36q.pdf 


\section{Macrothink

Phoenix, A. (2004). Learning styles and gender. In H. Claire (Ed.), Gender in education 3-19: A fresh approach. The Association of Teachers and Lectures: 33-41.

Reid, J. (1995). Learning styles in the ESL/EFL classroom. London: Heinle \& Heinle Publishers.

Reid, J. M. (Ed.). (1998). Understanding learning styles in the second language classroom. USA: Prentice Hall Regents.

Scarcella, R. (1990). Teaching language minority students in the multicultural classroom. Englewood Cliffs, NJ: Prentice-Hall/ Regents.

Stebbins, C. (1995). Culture-specific perceptual - learning - style preferences of post secondary students of English as a second language. In J. M. Reid (Ed.), Learning styles in the ESL/EFL classroom (pp. 108-117). New York: Heinle \& Heinle Publishers.

Svinicki, M. (ed.) (1999). Teaching and learning on the edge of the millennium. New Directions for Teaching and Learning, 80. San Francisco: Jossey-Bass. https://doi.org/10.1002/t1.8000

Tyacke, M. (1998). Learning style diversity and the reading class: Curriculum design and assessment. In J. Reid (Ed.), Understanding learning styles in the second language classroom. Prentice Hall Regents.

Violand-Sanchez, E. (1995). Cognitive and learning styles of high school students: Implications for ESL curriculum development. In J. Reid (Ed.), Learning styles in the ESL/EFL classroom. Heinle \& Heinle.

Yu Cheng, M. H., \& Banya, K. (1998). Bridging the gap between teaching styles and learning styles. In J. Reid (Ed.), Understanding learning styles in the second language classroom. Prentice Hall Regents.

\section{Appendix}

Appendix 1. Perceptual Learning-Style Preference Questionnaire

\section{Directions:}

People learn in many different ways. For example, some people learn primarily with their eyes ( visual learners) or with their ears ( auditory learners); some people prefer to learn by experience and/or by "hands-on" tasks ( kinesthetic or tactile learners); some people learn better when they work alone, while others prefer to learn in groups.

This questionnaire has been designed to help you identify the way(s) you learn best- the way(s) you prefer to learn.

Read each statement on the following pages. Please respond to the statements. AS THEY APPLY TO YOUR STUDY OF ENGLISH. Decide whether you agree or disagree with each statement. For example, if you strongly agree, mark: 


\begin{tabular}{|c|c|c|c|c|}
\hline 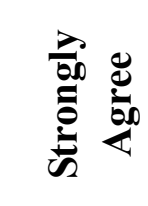 & 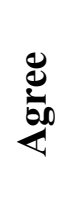 & 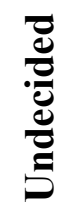 & 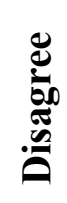 & 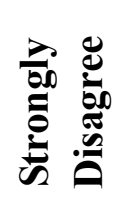 \\
\hline $\mathbf{X}$ & & & & \\
\hline
\end{tabular}

Please respond to each statement quickly, without too much thought. Try not to change your responses after you choose them. Please use a pen to mark your choices.

\begin{tabular}{|c|c|c|c|c|c|}
\hline Questionnaire statements & 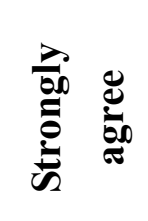 & 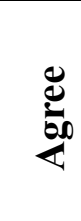 & 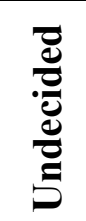 & 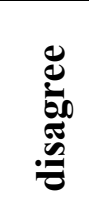 & 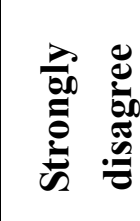 \\
\hline $\begin{array}{l}\text { 1. When the teacher tells me the instructions, I } \\
\text { understand better. }\end{array}$ & $\square$ & $\square$ & $\square$ & $\square$ & $\square$ \\
\hline 2. I prefer to learn by doing something in class. & $\square$ & $\square$ & $\square$ & $\square$ & $\square$ \\
\hline 3. I get more work done when I work with others. & $\square$ & $\square$ & $\square$ & $\square$ & $\square$ \\
\hline 4. I learn more when I study with a group. & $\square$ & $\square$ & $\square$ & $\square$ & $\square$ \\
\hline 5. In class, I learn best when I work with others. & $\square$ & $\square$ & $\square$ & $\square$ & $\square$ \\
\hline $\begin{array}{l}\text { 6. I learn better by reading what the teacher writes on } \\
\text { the chalkboard. }\end{array}$ & $\square$ & $\square$ & $\square$ & $\square$ & $\square$ \\
\hline $\begin{array}{l}\text { 7. When someone tells me how to do something in } \\
\text { class, I learn it better. }\end{array}$ & $\square$ & $\square$ & $\square$ & $\square$ & $\square$ \\
\hline 8. When I do thing in class, I learn better. & $\square$ & $\square$ & $\square$ & $\square$ & $\square$ \\
\hline $\begin{array}{l}\text { 9. I remember things I have heard in class better than } \\
\text { things I have read. }\end{array}$ & $\square$ & $\square$ & $\square$ & $\square$ & $\square$ \\
\hline $\begin{array}{l}\text { 10. When I read instructions, I remember them } \\
\text { better. }\end{array}$ & $\square$ & $\square$ & $\square$ & $\square$ & $\square$ \\
\hline $\begin{array}{l}\text { 11. I learn more when I can make a model of } \\
\text { something. }\end{array}$ & $\square$ & $\square$ & $\square$ & $\square$ & $\square$ \\
\hline 12. I understand better when I read instructions. & $\square$ & $\square$ & $\square$ & $\square$ & $\square$ \\
\hline 13. When I study alone, I remember things better. & $\square$ & $\square$ & $\square$ & $\square$ & $\square$ \\
\hline $\begin{array}{l}\text { 14. I learn more when I make something for a class } \\
\text { project. }\end{array}$ & $\square$ & $\square$ & $\square$ & $\square$ & $\square$ \\
\hline 15. I enjoy learning in class by doing experiments. & $\square$ & $\square$ & $\square$ & $\square$ & $\square$ \\
\hline 16. I learn better when I make drawings as I study. & $\square$ & $\square$ & $\square$ & $\square$ & $\square$ \\
\hline
\end{tabular}




\begin{tabular}{|l|l|l|l|l|l|}
\hline $\begin{array}{l}\text { 17. I learn better in class when the teacher gives a } \\
\text { lecture. }\end{array}$ & $\square$ & $\square$ & $\square$ & $\square$ \\
\hline 18. When I work alone, I learn better. & $\square$ & $\square$ & $\square$ & $\square$ & $\square$ \\
\hline $\begin{array}{l}\text { 19. I understand things better in class when I } \\
\text { participate in role playing. }\end{array}$ & $\square$ & $\square$ & $\square$ & $\square$ & $\square$ \\
\hline 20. I learn better in class when I listen to someone. & $\square$ & $\square$ & $\square$ & $\square$ & $\square$ \\
\hline $\begin{array}{l}\text { 21. I enjoy working on an assignment with two or } \\
\text { three classmates. }\end{array}$ & $\square$ & $\square$ & $\square$ & $\square$ & $\square$ \\
\hline $\begin{array}{l}\text { 22. When I built something, I remember what I have } \\
\text { learned better. }\end{array}$ & $\square$ & $\square$ & $\square$ & $\square$ & $\square$ \\
\hline 23. I prefer to study with others. & $\square$ & $\square$ & $\square$ & $\square$ & $\square$ \\
\hline $\begin{array}{l}\text { 24. I learn better by reading than listening to } \\
\text { someone. }\end{array}$ & $\square$ & $\square$ & $\square$ & $\square$ & $\square$ \\
\hline 25. I enjoy making something for a class project. & $\square$ & $\square$ & $\square$ & $\square$ & $\square$ \\
\hline $\begin{array}{l}\text { 26. I learn best in class when I can participate in } \\
\text { related activities. }\end{array}$ & $\square$ & $\square$ & $\square$ & $\square$ & $\square$ \\
\hline 27. In class, I work better when I work alone. & $\square$ & $\square$ & $\square$ & $\square$ & $\square$ \\
\hline 28. I prefer working on projects by myself. & $\square$ & $\square$ & $\square$ & $\square$ & $\square$ \\
\hline $\begin{array}{l}\text { 29. I learn more by reading textbooks than listening } \\
\text { to lectures. }\end{array}$ & $\square$ & $\square$ & $\square$ & $\square$ & $\square$ \\
\hline 30. I prefer to work by myself. & $\square$ & $\square$ & $\square$ & $\square$ & $\square$ \\
\hline
\end{tabular}

Appendix 2. Self-Scoring Sheet for Perceptual Learning Style preference by Reid (1995):

There are five statements for each learning category in this questionnaire. The questions are grouped below according to each learning style. Each question you answer has a numerical value:

\begin{tabular}{|c|c||c|c|c|}
\hline $\begin{array}{c}\text { Strongly Agree } \\
\text { (SA) }\end{array}$ & $\begin{array}{c}\text { Agree } \\
\text { (A) }\end{array}$ & $\begin{array}{c}\text { Undecided } \\
\text { (U) }\end{array}$ & $\begin{array}{c}\text { Disagree } \\
\text { (D) }\end{array}$ & $\begin{array}{c}\text { Strongly Disagree } \\
\text { (SD) }\end{array}$ \\
\hline \hline 5 & 4 & 3 & 2 & 1 \\
\hline \hline
\end{tabular}

Fill in the blanks below with the numerical value of each answer. For example, if answered strongly agree for statement 6 (a visual question), write a number $5(S A)$ on the blank next to question 6. 


\section{Visual \\ $6-5$}

When you have completed all the numerical values for Visual, add the numbers together.

Multiply the answer by 2, and put the total in the appropriate blank.

Follow this process for each of the learning style categories. When you are finished, look at the bottom of the scale that follows. It will help you determine your

major learning style preference(s):

minor learning style preference(s):

negligible learning style(s):

If you need help, ask your teacher.
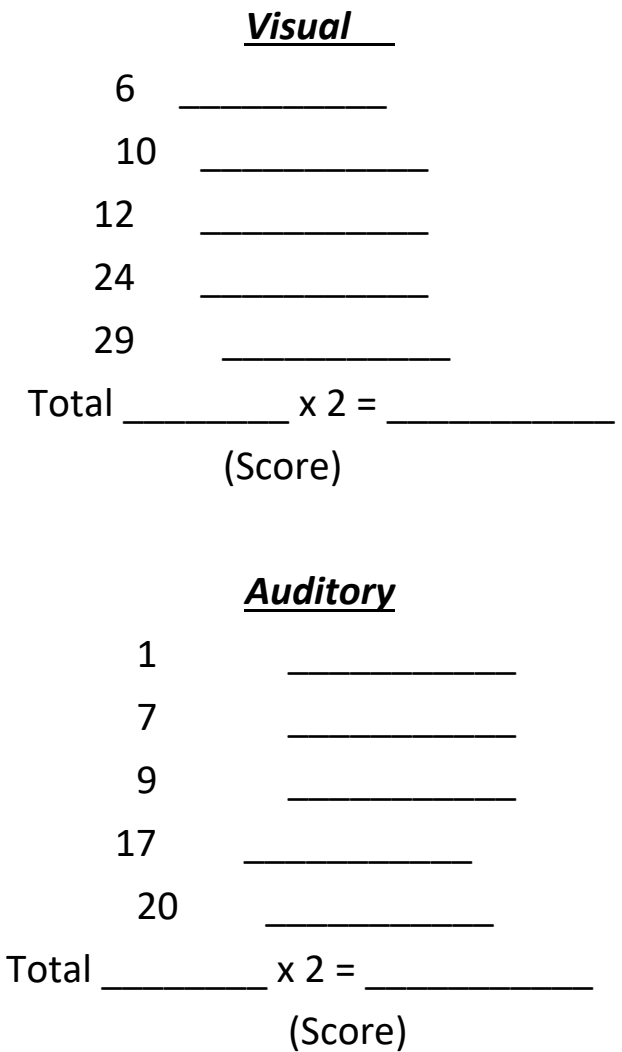

Kinesthetic

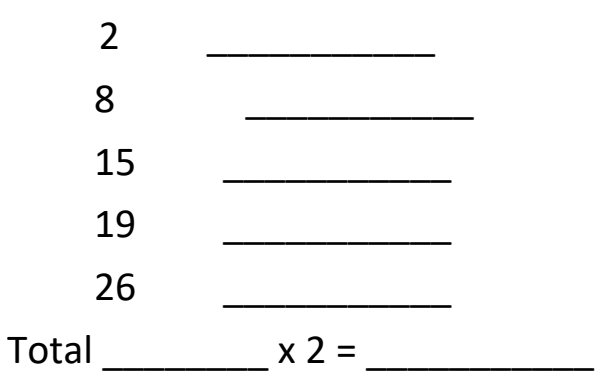

(Score)
Score: $38-50$

Score: 25- 37

Score: $0-24$

\section{Scoring Sheet}
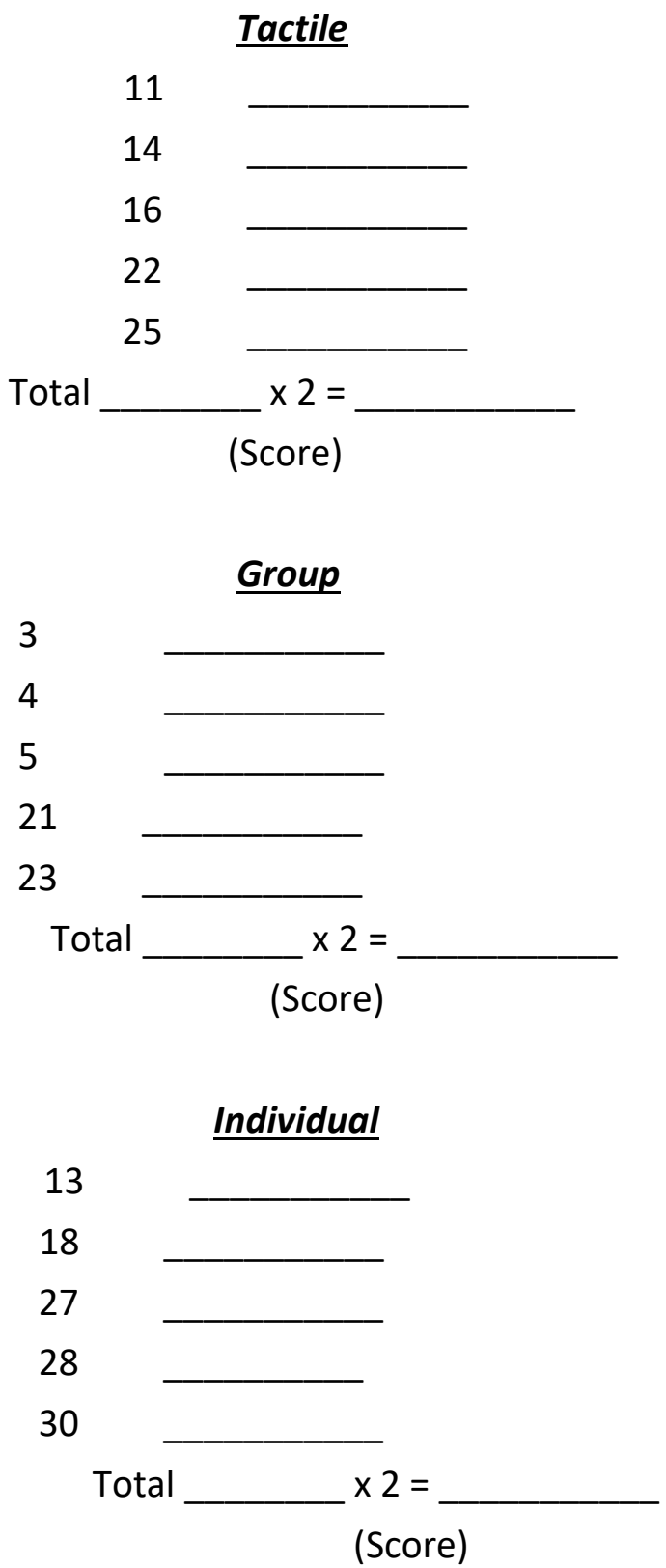
major learning style preference(s):

Score: $38-50$

minor learning style preference(s):

Score: $25-37$

negligible learning style(s):

Score: $0-24$

Appendix 3. Explanation of Perceptual Learning Style Preferences

Students learn in many different ways. The questionnaire you completed and scored showed which ways you prefer to learn English. In many cases, students' learning style preferences show how well students learn material in different situations.

The explanations of major learning style preferences below describe the characteristics of those learners. The descriptions will give you some information about ways in which you learn best.

Visual Major Learning Style Preference:

You learn well from seeing words in books, on the chalkboard, and in workbooks. You remember and understand information and instructions better if you read them. You don't need as much oral explanation as an auditory learner, and you can often learn alone with a book. You should take notes of lectures and oral directions if you want to remember the information.

Auditory Major Learning Style Preference:

You learn from hearing words spoken and form oral explanation. You may remember information by reading aloud or moving you lips as you read, especially when you are learning new material. You benefit from hearing audio tapes, lectures, and class discussion. You benefit from making tapes to listen to, by teaching other students, and by conversing with your teacher.

Kinesthetic Major Learning Style Preference:

You learn best by experience, by being involved physically in classroom experiences. You remember information well when you actively participate in activities, field trips, and role-playing in the classroom. A combination of stimuli-for example, and audio tape combined with an activity- will help you understand new material.

Tactile Major Learning Style Preference:

You learn best when you have the opportunity to do " hands-on" experiences with materials. That is, working on experiments in a laboratory, handling and building models, and touching and working with materials provide you with the most successful learning situation. Writing notes or instructions can help you remember information, and physical involvement in class related activities may help you understand new information. 


\section{Macrothink \\ Education and Linguistics Research \\ ISSN 2377-1356 \\ 2019, Vol. 5, No. 2}

Group Major Learning Style Preference

You learn more easily when you study with at least one other student, and you will be more successful completing work well when you work with others. You value group interaction and class work with other students, and you remember information better when you work with two or three classmates. This stimulation you receive from group work helps you learn and understand new information.

Individual Major Learning Style Preference

You learn best when you work alone. You think better when you study alone, and you remember information you learn by yourself. You understand new material best when you learn it alone, and you make better progress in learning when you work by yourself.

Minor Learning Styles

In most cases, minor learning styles indicate areas where can function well as a learner: Usually a very successful learner can learn in several different ways.

Negligible Learning Styles

Often, a negligible score indicates that you have difficulty learning in that way. One solution may be to direct your learning to your stronger styles. Another solution might be to try to work on some of the skills to strengthen you learning style in the negligible area.

\section{Copyright Disclaimer}

Copyright reserved by the author(s).

This article is an open-access article distributed under the terms and conditions of the Creative Commons Attribution license (http://creativecommons.org/licenses/by/3.0/). 